\title{
SUSTAINABLE DEVELOPMENT AND ECOLOGICAL RESPONSIBILITY OF BUSINESS
}

\author{
Viktoria KRYKUN', \\ Institute of International Relations of Taras Shevchenko National University of Kyiv, Ukraine
}

\begin{abstract}
Today sustainable development is a widely used term, which has been increasingly influential in recent years. Debates about sustainability no longer consider sustainability solely as an environmental concern, but also incorporate economic and social dimensions. However, while a social and economic dimensions of sustainable development are widely discussed, environmental degradation becomes more and more crucial each year and is likely to reduce human well-being all across the world within the next few decades. The purpose of the paper is to analyse ecological 'pillar' of sustainable development, its historical background, main steps towards implementation of 'new global environmental rules for society. Methodology. The paper is based on statistical information from public sources, reports of different international organizations and institutions, which are used to stress and underline main crucial points of research. Results of the survey show, that environmental quality, economic development and social well-being are interdependent and the main aim of international institutions, independent countries, businesses and society is to achieve environmentally sustainable development. Environmental issues make strong impact on modern economy. Responsible global strategy of development provides the whole society with rules, how 'wise' technological changes and economic policy can make industrial production processes less polluting and less resource intensive but yet more productive and profitable. Practical implications. Strategy of sustainable development and it's three basic dimensions have found practical implication in one complex model, which illustrates the level of development of each country - the Human Development Index, which is focusing on three basic dimensions of human development: life expectancy at birth, mean years of schooling and expected years of schooling and gross national income per capita. Another data, which is used on the basis of sustainable development indicator's' is Environmental Performance Index - method of quantifying and numerically marking the environmental performance of a state's policies, which was designed to supplement the environmental targets set forth in the United Nations Millennium Development Goals. All these indicators and indexes should be a platform for modern successful socio-economic development of Ukraine. Value/originality. The theme of sustainable development has long history and levels of development, but yet it is very popular and important for each country and the world as a whole. Many issues of this strategy of development depend not only from governments, but from the engines of economic growth - companies. Today the aim for businesses is to create higher standards of living and quality of life, proper ecological situation in the communities in which they operate, while still preserving profitability for stakeholders.
\end{abstract}

Key words: sustainable development, ecological responsibility, business social responsibility, indicators of sustainable development, Human Development Index, Environmental Performance Index.

JEL Classification: F63, F64, F50

\section{Introduction}

For most of the last couple of hundred years the environment has been largely seen as external to humanity. There was such an idea that resources are inexhaustible and it's not necessary to save them. As economy grew, new technologies were investigated, wide range of complex goods and services was proposed by companies, the environment was conceived as humanity's triumph over nature. The main idea till XX century was that human knowledge and technology could overcome all obstacles including natural and environmental ones. As Bacon, one of the founders of modern science stated, "The world is made for man, not man for the world'. This period of cooperation between human and nature is called Technological approach, which means, that the main role in this cooperation play people and the rules of nature cannot and shouldn't interrupt scientific, technological and social progress of humanity. Such approach has led to

Corresponding author:

${ }^{1}$ Department of International Business, Institute of International Relations of Taras Shevchenko National University of Kyiv.

E-mail: v.krykun@mail.ru 
the situation, when question of nature preservation turned into question of humanity survival. Biosphere can be stable and renewable if people don't pass through 'back off point' and ecological balance doesn't violate. Each ecosystem has the property that regulates its internal environment and tends to maintain a stable, relatively constant condition of properties such as temperature or $\mathrm{pH}$, which is called Homeostasis. In simple terms, it is a process in which the body's internal environment is kept stable, despite changes in external conditions. Because of very intensive anthropogenic and anthropogenic influence, today people face a lot of problems, such as reduction of untouched ecosystems, high temps of renewable natural resources consumption. Concern over air and water pollution rapidly spread to a range of other conditions - soil erosion, pesticide contamination, deforestation, declining animal populations and species, and so on - through the efforts of environmental scientists, activists, and policy-makers. One of the huge ecological problems, which has appeared because of intensive economic development, is agricultural chemicalization, which lead to increase number of mineral fertilizer and pesticides usage. In almost all cases such activities don't cause rise in crop capacity volumes, but vice versa, soil becomes worked out, and loses its fertility for many decades. Another problem concerns food security. While Earth population rises, there is over proportionate consumption of ecological clean products, and lack of minimum volume of food for biggest part of people all over the world. According to Environmental Performance Index Report 2016, air pollution is a growing global problem, worse in rapidly developing economies, like China and India, than in wealthy or very poor nations. More than 3.5 billion people, or half of the world's population, live in nations where average exposure to fine particulate matter exceeds levels the World Health Organization considers safe $\left(10 \mathrm{micrograms} / \mathrm{m}^{3}\right)$. One-third (1.3 billion) of these people live in the East Asia and Pacific region, where in China and South Korea more than 50 percent of their populations are exposed to unsafe levels of fine particulate matter. In India and Nepal, the percentage is nearly 75 percent. The number of people lacking access to clean water has been cut nearly in half from 960 million in the year 2000 to 550 million, or around 8 percent of the world's population, today, but still it isn't a good index. In other words, current populations and lifestyles are exhausting non-renewable resources like fossil fuels; creating shortages of renewable resources such as fresh water, fisheries, and forests; and generating accumulating levels of pollution, particularly hazardous wastes.

\section{Concept of sustainable development}

Such poor tendencies lead to immersion of another concept of cooperation between human and nature, which is called Ecological approach. The followers of this approach stress that people should work and develop in frames of natures' rules. Evolution of society is considered as part of nature evolution and is located on the second place vis-à-vis nature. Of course, such approach is supported by deep ecologists, who prioritizes the needs of nature, and isn't effective for modern socioeconomic development, but some it's theses might and should be include in strategy of humanity's well-being. So, game plan of humanity survival and development lies in golden middle between Ecological and Technological approaches. The first initiative, which tried to combine interests of further technical progress and environmental protection, was United Nations Conference on the Human Environment, which dates back to a Swedish initiative in the Economic and Social Council in 1968 and was held in Stockholm in 1972. The main purpose of the Conference was to alert world opinion to the growing danger of pollution, the rapid growth of human settlements and the degradation of soils and other natural resources, and to provide a basis for action to meet these problems (Vasseur, 1973). As the result, the Conference proposed two documents and one program, which aimed to protect and improve the environment for future generations. The first document was a Declaration on the Human Environment with its 26 principles, among which are that States have the sovereign right to exploit their own resources and the responsibility to ensure that, in doing so, they do not harm the environment of other States or of areas beyond the limits of national jurisdiction; and that States shall co-operate to develop international law to provide compensation for victims of pollution that crosses over national boundaries. The Declaration states further that the capacity of the earth to produce vital renewable resources must be maintained and restored or improved wherever practical. Another principle declares that States shall take all possible steps to prevent pollution of the seas by substances that are liable to create hazards to human health, harm living resources, damage amenities or interfere with legitimate uses of the seas. The Declaration also stresses the importance of scientific research and development in the context of environmental problems. Another document is an Action Plan for the Human Environment which includes 109 recommendations and guidelines for Governments and international organizations in sphere of control over contamination from man-made pollutants, management of the use of natural resources, improvement of the cities, and ways in which nations can co-operate to save and enhance their common heritage. Also, during the Conference on the Human Environment was proposed to establish body, which will be the leading global environmental authority that sets the global environmental agenda, promotes the coherent implementation of the environmental dimension of sustainable development within the United Nations system and serves as an authoritative advocate for the global environment. The United Nations Environment Programme was founded in June 1972 and today declare as its' global mission to provide leadership and encourage 
partnership in caring for the environment by inspiring, informing, and enabling nations and people to improve their quality of life without compromising that of future generations.

The UN's World Commission on Environment and Development, chaired by Gro Harlem Brundtland of Norway provided world with the term 'sustainable development', which is used today not only in environmental, social and economic spheres, but also in everyday language. This term came into use after the publication of the Brundtland Commission's report on the global environment and development in 1987. This commission defined sustainable development as 'development that meets the needs of the present without compromising the ability of future generations to meet their own needs' (Brundtland Commission, 1987). The report stresses that humanity, whether in an industrialized or a rural subsistence society, depends for security and basic existence on the environment; the economy and our well-being now and in the future need the environment. It also points to the planetwide interconnections: environmental problems are not local but global, so that actions and impacts have to be considered internationally to avoid displacing problems from one area to another by actions such as releasing pollution that crosses boundaries, moving polluting industries to another location or using up more than an equitable share of the earth's resources (Hopwood, Mellor and O’Brien, 2005).

Following the Brundtland definition, it is clear that 'needs' themselves change, so it is unlikely that those of future generations will be the same as those of the present generation (Redclift, 1993). Obviously development itself contributes to the characterization of 'needs', by helping to define them differently for each generation, and for different cultures. For example, according to United Nations Development Programme, the set of main new 17 Sustainable Development Goals, which were coined in the 2030 Agenda for Sustainable Development, are aimed to end poverty, fight inequality and injustice, and tackle climate change by 2030 . This is relatively new initiative, which was born at the United Nations Conference on Sustainable Development, Rio+20, in 2012, and which can stress on the main needs of nowadays and future generations and help to provide global strategy of development for all countries. The objective was to produce a set of universally applicable goals that balances the three dimensions of sustainable development: environmental, social, and economic. The Sustainable Development Goals replace the Millennium Development Goals, which in September 2000 rallied the world around a common 15-year agenda to tackle the indignity of poverty. The MDGs established measurable, universally-agreed objectives for eradicating extreme poverty and hunger, preventing deadly but treatable disease, and expanding educational opportunities to all children, among other development imperatives (2030 Agenda for Sustainable Development, 2015).

\section{Main indicators of sustainable development}

Sustainable development is often presented as being divided into three 'pillars': economy, environment and society (Kahn, 1995). Economic sustainability includes market allocation of resources, sustained levels of growth and consumption, an assumption that natural resources are unlimited. Social sustainability encompasses notions of equity, empowerment, accessibility, participation, sharing, cultural identity, and institutional stability. It seeks to preserve the environment through economic growth and the alleviation of poverty. Environmental sustainability involves ecosystem integrity, carrying capacity and biodiversity. It requires that natural capital be maintained as a source of economic inputs and as a sink for wastes. Resources must be harvested no faster than they can be regenerated. Wastes must be emitted no faster than they can be assimilated by the environment (Kahn, 1995).

Table 1

The paradigm of sustainable development in Agenda 21 as elaborated by Kahn

\begin{tabular}{|c|c|c|}
\hline \multirow{2}{*}{$\begin{array}{c}\text { Element } \\
\text { Economic }\end{array}$} & \multicolumn{2}{|c|}{ Criteria } \\
\cline { 2 - 3 } Sustainability & Growth & Productivity \\
\cline { 2 - 3 } Social Sustainability & Development & Trickle Down \\
\cline { 2 - 3 } & Equity & Participation \\
\cline { 2 - 3 } & Accessibility & Institutional \\
& Cultural Identity \\
\hline \multirow{2}{*}{$\begin{array}{c}\text { Environmental } \\
\text { Sustainability }\end{array}$} & Eco-System & \multirow{2}{*}{ Biodiversity } \\
\cline { 2 - 3 } & Carrying Capacity & \\
\hline
\end{tabular}

Source: Kahn, 1995

All these three dimensions of sustainable development should be connected and interlinked into one complex model, which illustrates the level of development of each country and denotes debilitated points. Such universal index - the Human Development Index (was developed by United Nations Development Programme) is focusing on three basic dimensions of human development: to lead a long and healthy life, measured by life expectancy at birth; the ability to acquire knowledge, measured by mean years of schooling and expected years of schooling; and the ability to achieve a decent standard of living, measured by gross national income per capita. The report which was published by United Nations Development Programme in 2015, titled 'Work for Human Development', ranks countries by Human Development Index and its components value and details the values of the three HDI components: longevity, education (with two indicators) and income (Table 2). The report argues that with better health and education outcomes and reductions in extreme poverty, 2 billion people have moved out of low human development levels in the last 25 years, the report says. 830 million people are classified as working poor who live on under $\$ 2.00$ a day. Over 200 million 
people, including 74 million youth, are unemployed, while 21 million people are currently in forced labour. The report stresses that with green growth, new jobs will be created, the nature of others will be transformed, and others will end altogether. These changes ideally should be supported by systems of social protection and safety nets. For example, around 45 million additional health workers will be needed to meet the health objectives of the Sustainable Development Goals. That would see the global health workforce increase in size from 34 million in 2012 to 79 million by 2030 .

In broad terms, the concept of sustainable development is an attempt to combine growing concerns about a range of environmental issues with socio-economic issues. The Brundtland Report and active discussions of sustainable development conception culminated with the first Earth Summit in Rio de Janeiro in 1992. At this Earth Summit diplomats from over 120 nations signed five pacts framing sustainable development as the overarching policy of the 21 st century. The 27 principles of The Rio Declaration on Environment and Development 'define the rights and responsibilities of nations as they pursue human development and well-being. Next document, Agenda 21, the framework for action proposed at the Earth Summit, was the call for partnerships between business and environmental groups. It is a comprehensive plan of action to be taken globally, nationally and locally by organizations of the United Nations System, Governments, and Major Groups in every area in which human impacts on the environment. The Statement of Principles on Forests avows the responsibility of countries to manage, conserve, and develop world forests in a sustainable manner. The Convention on Biological Diversity implores nations to 'adopt ways and means to conserve the variety of living species'. The United Nations Framework Convention on Climate Change seeks 'to stabilize greenhouse gases in the atmosphere at levels that will not dangerously upset the global climate system' (Keating, 1993).

\section{Ecological responsibility}

The Rio Declaration in 1992 reflected an increasing concern with global environmental issues: a concern that was to lead to the establishment of a number of institutional mechanisms to try and ensure that environmental problems could be managed more effectively. One of such mechanisms was the Kyoto protocol-the first and unique agreement between nations, which by means of economic instruments (International emissions trading, Clean development mechanism and Joint implementation) mandated country-by-country reductions in greenhouse-gas emissions. The framework pledged to stabilize greenhouse-gas concentrations at a level that would prevent dangerous anthropogenic interference with the climate system'. Under Kyoto, industrialised nations pledged to cut their yearly emissions of carbon, as measured in six greenhouse gases, by varying amounts, averaging 5.2\%, by 2012 as compared to 1990. Unfortunately, Kyoto protocol never met its objectives. Industrialised countries would be legally obliged to cut their greenhouse gas emissions 5\% on 1990 levels by 2008-2012. Developing countries including China, India, Brazil and South Africa (some of these countries are the largest contributing countries to the global warming problem) - would face no restriction on their emissions but were encouraged to adopt policies to promote greener growth. Another problem of Kyoto protocol is that many countries which are responsible for great part of the word's emissions, for example USA, haven't ratified Kyoto Protocol, are not obliged to reduce greenhouse gas emissions and there are no international instruments how to force or convince countries to take certain obligations on international level. So, this document has a lot of weak spots and today international community is seeking for new methods of ecological regulation and sustainable development. One of such new steps towards solving climate change problem was Paris Climate Agreement, which was adopted in 2015. The agreement sets out a global action plan to put the

Table 2

Top 10 countries with very high human development in Human Development Index, 2014

\begin{tabular}{|c|l|c|c|c|c|c|c|}
\hline & & $\begin{array}{c}\text { Human } \\
\text { Development } \\
\text { Index (HDI) }\end{array}$ & $\begin{array}{c}\text { Life expectancy } \\
\text { at birth }\end{array}$ & $\begin{array}{c}\text { Expected years } \\
\text { of schooling }\end{array}$ & $\begin{array}{c}\text { Mean years } \\
\text { of schooling }\end{array}$ & $\begin{array}{c}\text { Gross national } \\
\text { income (GNI) } \\
\text { per capita }\end{array}$ & $\begin{array}{c}\text { GNI per capita } \\
\text { rank minus HDI } \\
\text { rank }\end{array}$ \\
\hline HDI rank & Country & Value & (years) & (years) & (years) & $(2011$ PPP \$) & \\
\hline 1 & Norway & 0.944 & 81.6 & 17.5 & 12.6 & 64,992 & 5 \\
\hline 2 & Australia & 0.935 & 82.4 & 20.2 & 13.0 & 42,261 & 17 \\
\hline 3 & Switzerland & 0.930 & 83.0 & 15.8 & 12.8 & 56,431 & 6 \\
\hline 4 & Denmark & 0.923 & 80.2 & 18.7 & 12.7 & 44,025 & 11 \\
\hline 5 & Netherlands & 0.922 & 81.6 & 17.9 & 11.9 & 45,435 & 9 \\
\hline 6 & Germany & 0.916 & 80.9 & 16.5 & 13.1 & 43,919 & 11 \\
\hline 6 & Ireland & 0.916 & 80.9 & 18.6 & 12.2 & 39,568 & 16 \\
\hline 8 & United States & 0.915 & 79.1 & 16.5 & 12.9 & 52,947 & 3 \\
\hline 9 & Canada & 0.913 & 82.0 & 15.9 & 13.0 & 42,155 & 11 \\
\hline 9 & New Zealand & 0.913 & 81.8 & 19.2 & 12.5 & 32,689 & 23 \\
\hline
\end{tabular}

Source: Human Development Report, 2015 
world on track to avoid dangerous climate change by limiting global warming to well below $2^{\circ} \mathrm{C}$, because, according to different investigations, if greenhouse gas emissions continue to rise, we will pass the threshold beyond which global warming becomes catastrophic and irreversible. Also, governments agreed on the need for global emissions to peak as soon as possible, recognising that this will take longer for developing countries. The EU and other developed countries will continue to support climate action to reduce emissions and build resilience to climate change impacts in developing countries. Also, they intend to continue their existing collective goal to mobilise USD 100 billion per year until 2025 when a new collective goal will be set. The EU will cut its emissions by $40 \%$, compared with 1990 levels, by 2030 . The US will cut its emissions by $26 \%$ to $28 \%$, compared with 2005 levels, by 2025 . China will agree that its emissions will peak by 2030 (Harvey, 2015).This Climate agreement will be opened for signature for one year on 22 April 2016 and will enter into force after 55 countries that account for at least $55 \%$ of global emissions have deposited their instruments of ratification, therefore the US as the world's biggest emitter should join it.

According to the method of quantifying and numerically marking the environmental performance of a state's policies, which was designed to supplement the environmental targets set forth in the United Nations Millennium Development Goals - the 2016 Environmental Performance Index (EPI) - the top five countries, which are making progress addressing some environmental issues, are Finland, Iceland, Sweden, Denmark and Slovenia. EPI's Climate and Energy indicators primarily signal how countries are decarbonising economic growth rather than whether their climate policies are having a tangible effect. These indicators cannot point to underlying drivers of decarbonisation, whether they are due to economic decline or through concerted policy effort. Denmark, for instance, has made strong commitments to reduce emissions through increasing efficiency and renewable energy production. Singapore, as a result of its high urban density, has been able to lower its carbon intensity relative to economic peers over the last decade. Other countries, such as Russia, are likely overachieving compared to economic peers due to recession rather than ambitious climate efforts (EPI Report, 2016).

\section{Business social responsibility in context of sustainable development}

Global environmental situation depends on each country, each society and each company, which produce some goods and services. Collaboration between these three parties gives positive results, which are reflected on reduction of atmosphere pollution, water and land resources, resources-saving technologies adoption, utilization and repeated usage of waste products, flora and fauna renewal programs and many others. After initial

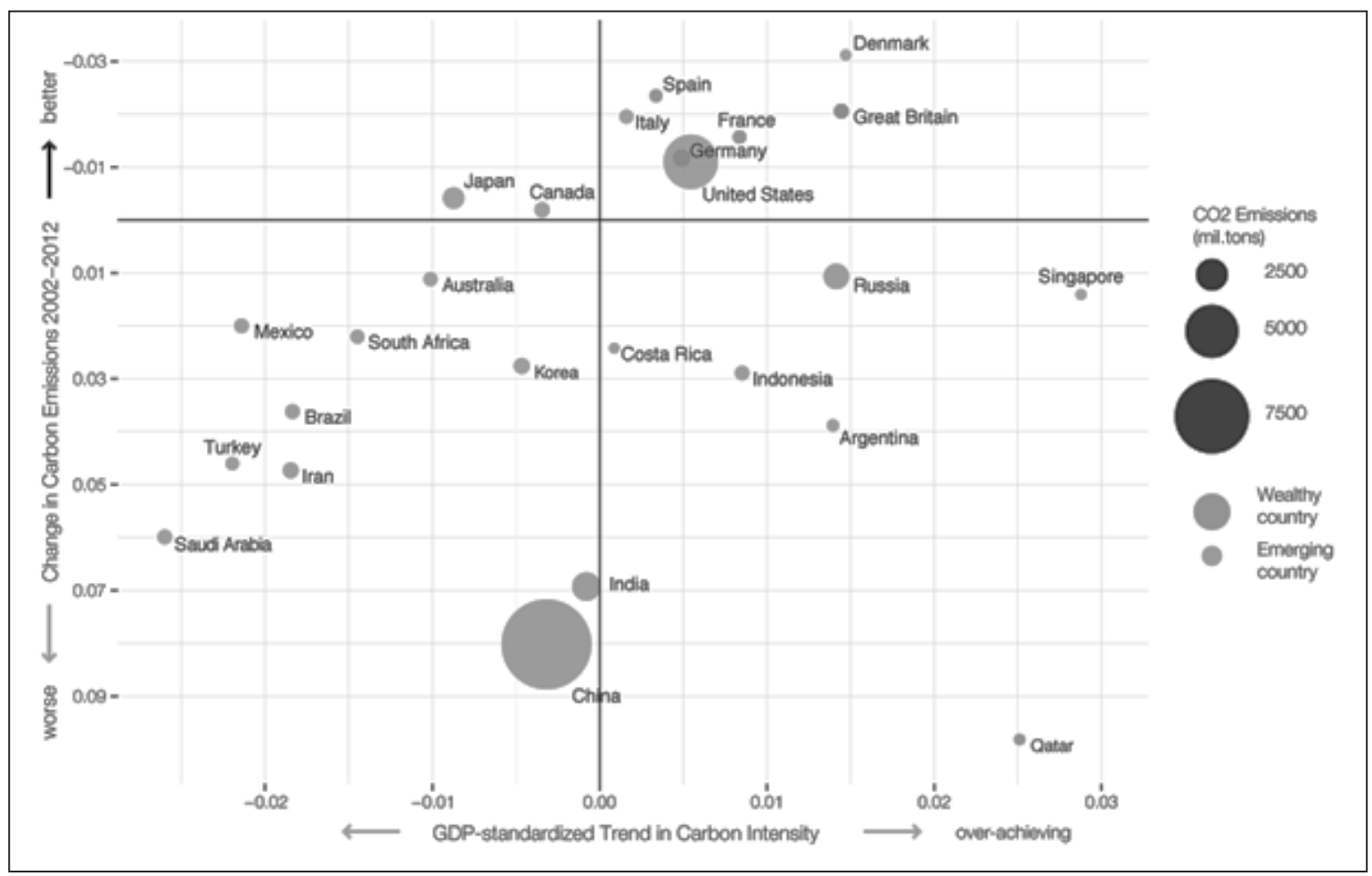

Fig. 1. Climate change performance in the 2016 Environmental Performance Index for selected top carbon-emitting countries, gauged according to the GDP-standardized Trend in Carbon Intensity and Trend in Carbon Emissions, Environmental Performance Index 2016 
reluctance, 95\% of large companies in Europe and the USA now believe that sustainable development is important. Over 150 of the world's major companies in mining, oil and gas, auto, chemicals, logging, banking and finance, cement, electricity generation, drugs and biotechnology are members of the World Business Council for Sustainable Development (WBCSD, 2001). Almost all huge multiand international companies adopt different business responsible initiatives, which support country, society and environment. Companies operating in different socioeconomic contexts and sectors address very different sustainability issues. Although some of these give greater attention to social issues and sustainable development, some to innovation and improved reputation, some to wider relationships and business sustainability. But all such socially responsible activities are closely linked with three main 'pillars' of sustainable development - economy, society and environment. As J. McGuire stressed in his definition of social responsibility of business - 'the corporation must take an interest in politics, in the welfare of the community, in education, in the 'happiness' of its employees, and, in fact, in the whole social world about it. Therefore, business must act 'justly', as a proper citizen should' (McGuire, 1963).

\section{Conclusions}

Over the past few years, sustainable development has emerged as the latest development catchphrase. A wide range of non-governmental as well as governmental organizations have embraced it as the new paradigm of development. Many companies integrate different social initiatives into their global strategies and succeed in them. Sustainable development very often is interpreted as 'sustained growth', 'sustained change', or simply 'successful' development. As a result, business social responsibility can be understood as a component of new systems of societal governance. Today the aim for businesses is to create higher standards of living and quality of life, proper ecological situation in the communities in which they operate, while still preserving profitability for stakeholders. Companies not only are engaged with their stakeholders but are themselves stakeholders alongside governments and civil society.

\section{References}

2030 Agenda for Sustainable Development. (2015). United Nations Development Programme.

Agenda 21. (1992). United Nations Conference for Environment and Development, Rio de Janeiro.

Basiago, A. (1999). Economic, social, and environmental sustainability in development theory and urban planning practice. The Environmentalist 19: 145-161.

Brundtland Commission. (1987). Our Common Future. Oxford University Press: Oxford.

Environmental Performance Index Report. (2016). Yale University.

Harvey, F. (2015). Everything you need to know about the Paris climate summit and UN talks, The Guardian.

Hopwood, B., Mellor, M., O’Brien, G. (2005). Sustainable Development: Mapping Different Approaches. Sustainable Development 13: 38-52.

Human Development Report (2015). United Nations Development Programme.

Kahn, M. (1995). Concepts, definitions, and key issues in sustainable development: the outlook for the future. Proceedings of the 1995 International Sustainable Development Research Conference, Manchester, England, Keynote Paper, 2-13.

Keating, M. (1993). The Earth Summit's agenda for change. Geneva: Centre for Our Common Future, viii, x, 12-13: 63-67.

Kothari, R. (1990). Environment, technology and development. In Ethics of Environment and Development, Belhaven: London; 27-35.

Kyoto protocol to the United Nations framework convention on climate change. (1998). United Nations.

Lee, K. (2000). Global sustainable development: its intellectual and historical roots. In Global Sustainable Development in the 21st Century, Edinburgh University Press: Edinburgh; 31-47.

McGuire, J.W. (1963). Business and society. New York: McGraw-Hill.

Redclift, Mr. (1993). Sustainable development: needs, values, rights. Environmental Values 2: 3-20.

Vasseur, E. United Nations conference on the human environment. Report. (1973). Water Research Pergamon Press, Vol. 7: 1227-1233.

World Business Council for Sustainable Development. (1998). Trade Environment and Sustainable Development: a Briefing Manual. World Business Council for Sustainable Development: Geneva. 
Vol. 2, No. 1, 2016

\section{Виктория КРИКУН}

\section{УСТОЙЧИВОЕ РАЗВИТИЕ И ЭКОЛОГИЧЕСКАЯ ОТВЕТСТВЕННОСТЬ БИЗНЕСА}

Аннотация. Сегодня устойчивое развитие - это широко используемая, популярная и влиятельная концепция, которая уже давно основывается не только на экологической составляющей, но и на социальном и экономическом измерениях. В то время как социальные и экономические факторы устойчивого развития широко обсуждаются, экологическая деградация с каждым годом все больше усугубляется, и негативно влияет на благосостояния социума. Целью работы является анализ экологической составляющей концепции устойчивого развития, исторических вех ее становления, основных этапов имплементации новых глобальных экологических правил. Методология. Статья основывается на статистической информации из официальных источников, отчетов международных организаций и институций. Результаты исследования показывают, что все три индикатора - качество окружающей среды, экономическое развитие и благосостояние социума - взаимосвязаны и основной целью международных институций, стран, бизнесов и общества есть достижение экологически устойчивого развития. Экологические проблемы очень сильно влияют на экономический рост. Глобальная стратегия развития, основывающаяся на социальной ответственности, обеспечивает общество сводом правил для разумных технологических нововведений и экономической политики, которые делают процессы промышленного производства экологически чистыми и менее ресурсозатратными, но в то же время более продуктивными и прибыльными. Практическое значение. Одним из основных инструментов концепции устойчивого развития является Индекс человеческого развития - интегральный показатель, рассчитываемый ежегодно для межстранового сравнения и измерения уровня жизни, грамотности, образованности и долголетия, который рассматривается в данной статье. Еще один показатель - Индекс экологической эффективности, комбинированный показатель, который измеряет достижения страны с точки зрения состояния экологии и управления природными ресурсами, также основывается на принципах и целях устойчивого развития. Все эти индикаторы и индексы должны послужить платформой современного социоэкономического развития Украины. Значение/оригинальность. Тема устойчивого развития имеет достаточно длинную историю и многочисленные этапы развития, но до сих пор остается популярной и важной для каждой страны и мира в целом. Многие аспекты данной стратегии развития зависят не только от правительств, но и от основных «двигателей» экономического роста - бизнеса. Сегодня целью бизнеса является создание высоких стандартов жизни, надлежащей экологической ситуации в странах пребывания, оставаясь в то же время прибыльными для своих акционеров. 